\title{
A Question of Time: Relations Between Age and Business Success
}

\author{
Julianna Nádai ${ }^{1}$ and Anna Garai ${ }^{1}$
}

\begin{abstract}
Our paper aims to find answers to the question how much business success negotiation success is determined by the business partners age and the amount of time spent in various fields of economy. In the 21 st century it seems to be a global phenomenon that business negotiators' ages tend to decrease due to the digitalization of business processes. In Central Eastern Europe this move is likely to be accelerated in the past 15 years. This paper presents parts of a research into the role of the effect of age versus business experience. Generation gaps between Hungarian business partners is obviuous as they have developed different corporate behavior styles. Thus, the factors age and generation are dominant in negotiations between two nations as differences in cultures also make negotiation situations more subtle. In our research we introduced age-related dichotomies which provide a theoretical framework for research can focus on practical results in a well-defined system, by taking existing models into account as well. In our paper we describe generation dependent business behavior in terms of Hungarian - German relations.
\end{abstract}

Keywords: age related dichotomies, research, business, negotiations, cultural differences

\section{Introduction}

The present study aims at revealing a topic which has been researched from various aspects for many years. We focus on the specific characteristics of communication between companies of various nations in Hungary. The paper is to reveal both theoretical and practical ways of how corporate communication is affected by regional specifics. We mainly focus on companies of German ownership and management seated in Hungary.

To have even more proper and successful business processes, the international companies are striving for a conscious improvement of corporate communication at institutional level (Handy 1993, Ablonczy and Tompos 2015, Cleveland 2003). Effective communication strategies can contribute to diminishing gaps emerging from cultural and age differences. In the present study we focus on management and negotiators' generation gaps as they have developed different corporate behavior styles (Kecskés 2014). The aim of the paper is to reveal how much age differences or generation gaps can influence negotiation practices. Thus we created a dichotomy model based on already existing models to highlight the most important characteristic features of negotiation styles.

In the next paragraph we will describe the methodology of research and modeling. Then we will present the basic models as starting points and carry out a content analysis strongly related to intercultural negotiations. Next, we detail our new dichotomy model 
on the role of age gaps in business relations and finally we draw conclusions and define future research potentials.

\section{Research methodology}

The present study is an exploratory and diagnostic research, where the method of research is based on literature overview and semi-structured interviews with management of German oriented companies. A basic aim is to give a detailed descriptive analysis of behaviors where we wished to set a system of typical characteristics and distinguishing features of management at companies in the region. After revealing reasons and relations and formulating conclusions, the present study can also be regarded as an explanatory research. In the interviews questions are asked both from Hungarian and German managers about each other's corporate communication characteristics based on cooperation experience. This study gives an insight into how German partners see their Hungarian partners' communication and how they interpret it during negotiations. In the interviews we asked 17 middle managers and CEOs of German oriented companies seated in the Western Hungarian region.

The method of semi-structured interview is chosen for because it allows a relatively open framework for research, where the questions are also formulated during the interview depending on the answers of the respondents. During the face-to-face interview it is possible to get reasons and explanations with the answers and the interviewer has the chance to interpret and ask for clarifying as well, not just to get but give information on the current issue (Babbie, 2013; Andorka, 2002; Héra and Ligeti, 2006). The respondents give a wide perspective of development as a process, causes and reasons, relations and context. During the interview we can verify the content of what is said reflecting the respondents' verbal and nonverbal or metacommunication (Geertz, 2008). The respondents usually tend to give answers instinctively which they deem to be expected and this way they project a standard idealistic view of their companies. These answers can be tackled easier than doing so in surveys. The interviews are made on the base of stratified sampling, where the respondents were selected regarding the size of company, how long it has been on the market or having foreign business partners. Our aim is to make a deep and detailed study on a well identified issue, so the number of respondents is fairly limited (17).

We carried out cross-sectional research and at present there is no longitudinal research in the research plan. However, based on a detailed secondary literature study, earlier publications and the results of research made in the preparatory phase, it is possible to draw up a development dynamics of the region like in research analysis on the state of the previous decade by Hardi and Nárai (2001). The reason for choosing Germany as a basis of comparison is that German-Hungarian business contacts have been accelerated in the last two decades which is rooted both in political and economic factors. After the political change in Hungary (1990), business partnership between Hungary and Germany was triggered, and grew by $32 \%$ compared to the $80 \mathrm{ies}$ (http://www.ksh.hu/stadat). Due to the high quality level of Hungarian service companies there is a great demand for Hungarians at German companies. In spite of the relatively small territory of Hungary, it is important to note that regional social, economic and cultural and differences within 
Hungary do apply in various regions. In the present study we focus on companies seated in the most developed north-west region of Hungary (Györ-Moson-Sopron county), at the Hungarian-Austrian border. Regional differences and specifics have been widely researched concerning culture and corporate culture by using different sets of criteria and dimensions (Davidsson, 1995; Dolan et al. 2004; Beugelsdijk 2006; Lenartowicz and Roth 2001; Girlando 2004). Hofstede (2011) studied 299 regions in 29 countries and stated that regions overwhelmingly cluster along national lines based on cultural values (Kaasa and Vadi, 2014).

\section{Dichotomy models in the research}

In our research we applied dimensions of models already used in international culture researches (Hofstede, 2008; Trompenaars, 2008; House 2004, Hall, 1990; Gesteland, 1999). We also connected indicators to the single dimensions which are the basis of empirical research. In the operational phase we formulated questions based on existing dimensions often used in intercultural communication. The best way to study social phenomena, behavior patterns in different cultures is to use the following dimensions: hierarchy or equality relations, achievement or ascription orientation, flexible or strict schedules, individualistic or collectivistic perspective, low or high uncertainty avoidance. Fons Trompenaars (2008) formed seven dimensions based on empirical research, out of which six were used in our research. Similarly, Hofstede, Hall and Hampden-Turner made their cultural dimensions which contributed to revealing human relations to each other and orientation to time and space. To provide a better understanding of how Hungarians behave in business context and how German partners interpret their behavior, we must define the applied dichotomy dimensions, relevant to our research results.

The dimensions of universalism and particularism describe reliance on rules or reliance on human relationships and unique conditions. In universalistic societies members consider rules binding to everyone without any disobeying while particularists tend to rely on much looser written agreements (Trompenaars and Hampden-Turner, 2008:31).

Individualism vs. collectivism. Individualism implies loose social contacts and preference of the own interest and power. In business life the basic aim is getting a quick deal, as the main purpose of their lives is improving own living conditions and circumstances. In a collectivist society people prioritize social interests and not individual ones, where business deals are based on keeping long-term business relations (Trompenaars and Hampden, 2008:67).

Neutral and affective cultures are distinguished regarding their approach to emotions. In neutral societies there is no place for any emotions in business negotiations. In contrast, affective cultures accept expressing emotions, high tone and wide gestures.

Specific and diffuse cultures (defined as High context-low context cultures by Hall (1990). In specific cultures private sphere and professional sphere are completely separated and behavior is determined by context. In out-of-workplace programs you cannot experience any hierarchy between employers and employees. People's way of thinking is analytical, that is, they usually start handling problems starting from the whole going towards details. However, in diffuse cultures private and professional spheres are integrated. 
Managers from diffused cultures include behavior that takes place in employees' private and professional lives. Hierarchy in communication is also present at free programs.

Human relations are formed on the basis of exact, well-defined aspects, while conversations in diffuse cultures seem to be less oriented and not to have one direction. That is why specific communicators seem precise, open-minded and transparent, whereas communication in diffuse cultures has the character of tact, no transparency and less focus. Value judgment on communication partners is not dependent on situation and participants while the opposite is typical of diffuse cultures. (Trompenaars and Hampden-Turner 2008).

Achievement vs. ascription. Achievement oriented societies appreciate effective work which serves as a basis for social involvement. In business life achievement is equal with money, income and profit. Ascription orientation means more respect to family background, good education and respected jobs, where the hierarchy in business life depends on age and experience. Consequently, corporate structure is also determined by these traditions and managers are usually middle-aged and male (Trompenaars and Hampden-Turner 2008).

Time orientation. The concept time and role of future, present and past are interpreted in very different ways in different societies. Traditions and respect of predecessors have an effect on business negotiations, as the partners' conversation before and after deals mostly include topics like history, families and national issues. Present oriented societies reject the effect of past and future on the current flow of events, and they consider results of completed work and joy of the moment valuable. In future oriented societies planning and innovation have great emphasis. So, the interest of the younger generation is a priority as they take present resources as a key for using future opportunities. (Trompenaars/Hampden-Turner 2008:138).

\section{Results}

In this chapter we are giving a summary of results based on our content analysis. Our intention was to form questions in the survey where the described dichotomy models can be translated into practice. That is, based on the conclusions we can see how German and Hungarian managers see each other's communication strategies and how this effects everyday business cooperation. After searching appropriate literature, we give an insight into the result of the interviews with German managers on their experience of business communication with Hungarians. Based on the answers it is obvious that is not possible to categorize nations in one well defined dimension described in the dichotomy models.

To have a clear overview, after analyzing the answers we made three groups of respondents' utterances:

1. objective answers

2. formulating value judgment

3. advice and orders

1. Objective answers

Hungarians usually do not take part in social events. 
- Hungarians solve tasks themselves and do not delegate them to others.

- Hungarians carefully watch gestures and mimics.

- Hungarians do not initiate new actions in international work teams, but they rather expect partners to take initiatives.

2. Value judgment

- Hungarians are hard to know well.

- Hungarians are more considerate and patient than Germans.

- $\quad$ Older generations are circumstantial and hard to make a quick deal with.

- Black market is much less present in the agriculture sector than years before.

- Official documents and data are processed in an inappropriate and negligent.

3. Advice and orders (DOs and DON'Ts)

- Hungarians are proud you should not paternalize them.

- You should not have the same expectations with Hungarians as accepted in Germany.

- Hungarians' internal communication must be improved, exact definition of responsibilities and competencies are necessary.

- Hungarians' self-confidence must be confirmed by praising and acknowledgement.

- $\quad$ Require references about the Hungarian business partner.

The German respondents emphasized the strong presence of prevailing hierarchy in Hungarian corporate culture. They regard the missing definition of exact tasks and responsibilities an apparent failure which may lead to inconsequence and huge deficit. According to the German respondents official documents and data are processed in an inappropriate and negligent way in Hungary.

Trust is a core issue in terms of business relations, emphasized from various approaches by the respondents (Szöke 2014). On the one hand, in Hungary businessmen tend to include private life behavior in business, that is, friendship and personal relations serve as a strong basis for long term business contacts. On the other hand, Hungarians may misuse reliance. This requires the business partners to ask for references about the Hungarian partners prior to negotiations. Special attention should be paid to the written documentation in transportation and delivery processes. The respondents find it necessary to involve a mediating company for successful deals as foreigners, according to respondents, have hardly any chance to attain special local information. Besides, cheats and bribery must be carefully prevented. These ideas let us conclude that reliance is a key concern and a fairly ambiguous issue in Hungary. The German managers see some features of Hungarian businesspeople to be followed and the idea is formed in form of good advice or order. It was interesting to hear the German respondents' debated answers on some issues which shows that no generalization on a nation's business behavior can be made as personal experience may vary according to current situation and circumstances. To show the controversy there are some examples below:

- Hungarians can work well in teams $\leftrightarrow$ Hungarians cannot think in terms of networks, only their individual responsibilities are considered,

- Hungarians tolerate stress and are calmer than Germans $\leftrightarrow$ Hungarians have no stress tolerance, 
- $\quad$ delayed payment is an embarrassing problem $\leftrightarrow$ Hungarians keep deadlines of payment, - Official documents and data are processed in an inappropriate and negligent $\leftrightarrow$ Hungarians want to be aware of all details, even years before,

- Hungarians are flexible and creative with problem solving $\leftrightarrow$ individual, independent work is not typical, so all tasks have to be fixed and delegated by giving enough explanation for each work phase; they cannot solve problems alone but wait for an authentic authority to warn them of mistakes and they start to fix the problem just later.

The respondents' utterances below reflect exactly Gesteland's theory on 'loss of face' (Gesteland 1999) and interpretations which are connected to the responses by deal oriented and direct cultures. 'Face' has to do with dignity, self-confidence and reputation. If a businessman expresses sharp disagreement, it makes the counterpart to lose face. Loss of face can completely disrupt business relations and negotiations.

The list below reveals a complex set of likely behavior of Hungarians to avoid loss of their face:

- Hungarians are hard to know well, their speech is mysterious, they describe ideas, just beat about the bush, and speak too circumstantial, they do not mean what they say, they do not say 'no' directly, the use 'we will reconsider' instead, you have to read between the lines,

- they do not say explicitly if they cannot understand things, or are not competent or they have questions, it takes time for them to express their needs,

- Hungarians never complain, Hungarians do not admit their own mistakes, over evaluate their abilities and always find an excuse,

- Hungarians are proud you should not paternalize them as they are striving for harmony, delays and misunderstanding must be told them as they are not willing to speak about them.

\section{Generation gaps: dichotomy of age}

After content analysis it was clear that we could not only use the existing framework of dichotomy models but we need to introduce a new dimension. According to the respondents views concerning the role of age of involved business partners it is obvious that Germans seem to be more homogenous in terms of age while among Hungarians there are huge generation gaps. We must emphasize that the age and generation factor is dominant in negotiations between the two nations. Regarding the applied dichotomy model we have to add the aspect of age and generation to the existing model.

Due to the rapid dissemination of digital technology in the last decades of the 20th century (Prensky 2001) a big discontinuity has taken place concerning generation gaps and the way aquiring knowledge. The fast changing environment, working sphere requirements to employees, growing expectations of school achievement, new teaching and learning methods, expanding international economic and cultural relations make it necessary to be interconnected by using the latest technologies in all fields of life. To have a better understanding of differences in negotiation and working styles of two generations we need to define the terms of digital natives and digital immigrants. These terms refer to the generational switchover where people are defined by the technological culture which they're familiar with (Prensky 2008). Digital Natives are an innate new culture and are native speakers of digital technology. Digital Immigrants are not born into a digital world but have adopted many aspects and accents of the new technology. 
According to a digital native presenter Philipp Riederle (2013) the paradigm shift in the 21 century is inevitable as the value system of his generation has also shifted compared to past values. While the post-war culture generation focused on money, status and power in their working lives, the younger generation is rather eager to find sense in their activities and strive for self-fulfillment in their work. And also, they wish to work in an organization appropriate for realizing these aims. Without taking any risks of transformation of past focus points it is impossible to overcome barriers on the labor force market.

This concept is embedded in the behavior of young age businesspeople (digital natives) involved in international negotiations. Adaption to new challenges enables negotiators to deal both with communication or business problems in their stride.

But we have to answer the question how businessmen can today achieve appropriate knowledge? The age of digitalization requires different learning structures form businesspeople. It is clear today that knowledge cannot be acquired in a linear manner as there is a demand for a much faster and complex way to get information for specific purposes. To have an insight into prevailing learning tendencies we have to introduce the term of connectivism.

Connectivism is the integration of principles explored by chaos, network, and complexity and self-organization (Siemens 2012). In this theory the ability to connect fields, ideas and concepts are the most crucial skills. Facilitating continuous learning it is critical to maintain connections. Connectedness to other individuals, groups/teams and virtual networks can ensure a continuous resource of knowledge. Although, we have to note, decision making on choosing the most authentic and useful pieces of information may be a limitation to the theory of connectivism, so decision making can also be regarded as part of the learning process.

All these features can be applied when we deal with negotiation styles of various age groups. While digital immigrants (i.e older generation, born before 1980) were educated according to ideas of behaviorism (stimulus and response), cognitivism (processing meaning internally) or constructivism (assigning meaning internally), the younger generation's way of thinking and education is based on connectivism and networking, which definitely result in a completely different attitude to all phenomena in life, just like business negotiations. According to Barabási "nodes always compete for connections because links represent survival in an interconnected world" (Barabási 2002, p.106). Today business competences are also derived from making connections and not only personal experience matters.

Generation gaps between Hungarian business partners are obvious in other areas, as well: the younger generation is more flexible; they work faster and are less circumstantial than the older generation. There are specific differences in their political views, too. The younger businesspeople tend to be self-confident and like being seen as powerful capitalists. The older ones, in contrast, tend to follow collective or communist way of thinking. The generation gap is not merely a general social issue in Hungary but also can be regarded as a key factor when analyzing the success of business and negotiation (Konczosné, 2014).

Based on the answers of the German business partners Hungarians have the following characteristic features: hospitable, friendly, sociable, open-minded, helpful, calm and 
objective. The younger generation of business partners have high level of language knowledge, typically that of English. Their computer skills are very good and contacting via up-to-date technological devices is widespread with hardly any exceptions. The respondents emphasized that most companies do not find any difficulties in attaining and purchasing the most modern technological devices for contacting.

Considering the above results, we have to form a new dichotomy dimension regarding age of managers and its role in corporate behavior. Having seen and analyzing the responses we must give a special accent to the role of age in business processes. To have a better understanding of the outcome of business processes due to varying age groups involved, we must set up a potential variety of dichotomies which can contribute to more specific and detailed research in the future. Accordingly, we formed three versions of dichotomy regarding age.

1. Internal control - external control: Older generation makes decisions after consideration by taking traditional values into account. Contrarily, businessmen of the younger generation makes quick decisions following the accelerated world's expectations and do not really care moral obstacles as they want to meet the seemingly suggested expectations of the market.

2. Striving for competitiveness - striving for solidarity: The younger generation is typically taking more risks and adventures in business regardless of even negative consequences and keep themselves in a continuous competing situation. The older generation cannot exclude the extern circumstances in deals and make effort to reach solidarity.

3. Formal - informal (partly overlapping Gesteland's dimensions): The older generation endeavors to keep formality in conversations and appreciates status differences as a sign of respect. Status differences are not regarded crucial and formal interpersonal communication is widely accepted.

\section{Conclusion}

The present paper proves that the dichotomy models used in other countries and fields can be applied well in Hungary. The novelty of our research was that we added the agerelated dimension as a dichotomy to the already existing theories and described generation dependent business behavior in terms of Hungarian - German relations.

Thus, in everyday business interactions we could identify elements which were not modeled in existing dichotomy models and still are worth considering in this framework. It is obvious that our research also has got its limitations. The number of interviews must be raised to obtain a more reliable picture of tendencies. And also, research focus should be extended to more than two nations to see if the new dichotomy model can be verified on a wider scale.

\section{References}

Ablonczyné, M. L. (2013). Language, culture and communication in organisations In: Bostjan Antoncic (ed.) ABSRC 2013. Ljubljana: Gea College Faculty of Entrepreneurship. 10 p. Paper 56 
Ablonczy, M. L. - Tompos, A. (2014). Culture-related Aspects of Business and Corporate Communication. $\mathrm{n}$ Adamcová, Livia. (ed.) *Cudzie jazylky v premenach casu IV. Recenzovany żornik prevspevkov z mezdinarodnej vedeckej konferencie.* Bratislava: Vydavatelstvo EKONAM. pp. 205-210

Andorka, R. (2002). Bevezetés a sqociológiába. Budapest: Osiris Kiadó

Babbie, E. (2013). The practice of social research. Wandsworth: Cengage Learning

Barabási, A. L. (2002). Linked: The New Science of Networks, Cambridge, MA: Perseus Publishing,

Baumer, T. (2004). Handbuch Interkulturelle Kompeten₹: Zürich: Orell Füssli Verlag AG.

Beugelsdijk, S. et al. (2006). Toward a unified Europe: explaining regional differences in value patterns by economic development, cultural heritage and historical shocks. Regional Studies, 40(3), pp. $317-327$

Cleveland, J. N., Goldberg C. B, Shore L. M. (2003). Work Attitudes and Decisions as a Function of Manager Age and Employee Age. Retrieved from http://citeseerx.ist.psu.edu/viewdoc/download?doi=10.1.1.529.9410\&rep=rep1\&type=pdf

Davidsson, P. (1995). Culture, structure and regional levels of entrepreneurship In: Entrepreneurship and Regional Development. An International Journal. Volume 7, Issue 1. pp. 41-62

Dolan, S. L. et al. (2004). Exploratory study of within-country differences in work and life values: the case of Spanish business students. International Journal of Cross Cultural Management, 4(2), pp.157-180

Geertz, C. (2008). Dichte Beschreibung. Bemerkung zu einer bedeutenden Theorie von Kultur. In: Wirth, U. (ed.): Kulturwissenschaften. Frankfurt am Main: Suhrkamp Verlag.

Gesteland, R. (1999). Global Business Babaviour. Zürich: Orell Füssli Verlag.

Garai, A., Nádai, J. (2015). Entrepreneurs' value judgement system and personality profile In: Covarrubias Venegas, B., Fink, G., $\quad$ Mayrhofer, W. (ed.) Contemporary Approaches in Training \& Education for Cross-Cultural Competence - potentials, challenges and its limits. IACCM 2015 14th IACCM Annual Conference and 7 th CEMS/IACCM Doctoral Workshop. Wien, Austria, 2015.09.01-2015.09.03. Wien: Vienna University of Economics and Business, 2015. pp. 52-54.

Girlando, A. P. et al. (2004). An examination of Hofstede's paradigm of national culture and its malleability: Italy and US thirty years later. Journal of Transnational Management, 10(1), pp. 23-36

Hall, E. T., Hall, M. (1990). Understanding cultural differences. Yarmouth: Intercultural Press Handy, C. (1993). Understanding Organisations. London: Penguin Books

Hardi T. and Nárai M. (2001). A határ menti területek jellegzetességeinek átalakulása a 20. század végi Nyugat- Magyarországon. Tér és Társadalom, XV/ 2, pp. 107-130

Héra G. and Ligeti, Gy. (2006). Módszertan. A társadalmi jelenségek kutatása. Budapest: Osiris Kiadó

Hofstede, G. (2008), Lokales Denken, globales Handeln. Interkulturelle Zusammenarbeit und globales Management. München: Taschenbuch Verlag.

Kecskés, P. (2014). Az ipari parkok fejlődési sajátosságai és értelmezési különbségei a generációk véleményének tükrében. In: Tér - Gazdaság - Ember 2 (2:3) pp. 37-52.

Konczosné Szombathelyi, M. (2013). Reciprocal effects between regions and organizations. A study of European regional cultures and corporate embeddedness. Tér - Gazdaság - Ember, 2013/3, 1. 3. pp. 42-53.

Lenartowicz, T., Roth, K. (2001). Does subculture within a country matter: a cross-culture study ofmotivational domains and business performance in Brazil. Journal of International Business Studies, 32(2), pp. 305-325

Nádai, J. (2012), New Management Strategies of Small and Medium Sized Companies in Multicultural CEE In: Springer, R., Chadraba, P. (ed.) Proceedings of the 20th Annual Conference on Marketing and Business Strategies for Central and Eastern Europe. Wien, Austria, 06/12/1012 - 08/12/2012 Wien: Institute for Export Management Vienna University of Economics and Business, pp. 223-230

Garai, A. and Nádai, J. (2015). Értékítéletek és értéktesztek: Egy kérdőíves vizsgálat tanulságai In: Tompos Anikó , Ablonczyné Mihályka Lívia (szerk.) "Kitekintések - 25 éves a győri közgazdászképzés": Kautz Gyula Emlékkonferencia. Győr, Hungary, 11/06/2015Győr: Széchenyi István Egyetem Kautz Gyula Gazdaságtudományi Kar, Paper Garai_Nadai. 8 p.

Prensky, M. (2008). The 21st-Century Digital Learner, Retrieved from: http://www.edutopia.org/ikiddigital-learner-technology-2008 (4 May 2016)

Riederle, P. (2013). Auf Augenhöhe mit der neuen Arbeitswelt, Retrieved from: https:// businessreadyblog.wordpress.com/2013/10/14/auf-augenhohe-mit-der-neuenarbeitswelt/ (15 February 2016) 
Siemens, G. (2012). Learning Analytics and Educational Data Mining: Towards Communication and Collaboration, Retrieved from: http://users.wpi.edu/ rsbaker/LAKs $\% 20$ reformatting\% $\% 20 \mathrm{v} 2$.pdf Szőke, J. (2014). The Psychic Distance Paradox in Case of Austro-Hungarian Business

Cooperation INTERNATIONAL JOURNAL OF BUSINESS AND MANAGEMENT STUDIES 3:(2) pp. 473- 480.

Trompenaars, F., Hampden-Turner, C. (2008). Riding the Wawes of Culture, Understanding

Cultural Diversity in Business. London: Nicholas Brealey Publishing

http://www.ksh.hu/stadat (10 March 2016) 